\title{
Self-Handicapping and it's Relation to Self-Efficacy among Yarmouk University Jordanian Students
}

\author{
ADNAN YOUSEF ATOUM, ${ }^{*}$ ABDUL LATIF AL-MOMANI \\ and AHLAM MOHAMMED ASAYYAH
}

Counseling and Educational Psychology Dept. Yarmouk University, Shafiq Irshidat st. Irbid, Jordan.

\begin{abstract}
The significant of the current study is evident through limited research on the relationship between self-handicapping and self-efficacy. The study aimed at exploring self-handicapping and its relationship with self-efficacy and some demographic variables among a sample of Yarmouk University Jordanian students. The sample consisted of (793) male and female students at Yarmouk University that was selected randomly. To achieve the objectives of the study, two tools were used; the Rhodewalt (1990) Self-handicapping Scale and Almohsen (2006) Self-efficacy Scale. Reliability and validity indicators were obtained before using the scales. The results showed that self-handicapping among Yarmouk University students was average, and no statistically significant differences in self-handicapping due to gender, specialty and achievement. The results also showed a statistically negative correlation between the scores of self-handicapping as a whole and self-efficacy score and all of its dimensions except the behavioral efficacy dimension.
\end{abstract}

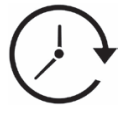

\section{Article History}

Received: 29 July 2019 Accepted: 30 September 2019

\section{Keywords}

Jordan;

Self-Handicapping;

Self-Efficacy;

Yarmouk University

Students.

\section{Introduction}

Individuals face many tasks and goals that vary in difficulties, which reflect on their chances of success or failure and beliefs about themselves. Prior experiences also often play a major role in determining motivation to future tasks or goals and individuals willingness to tackle new tasks in a phenomenon called self-handicapping (Al-Momani1 \& Atoum, 2016).

Palmer(2013) described self-handicapping behaviors creating individuals barriers to their success as an excuse for their failure. While others noted that self-handicapping is the process of setting obstacles

CONTACT Adnan Yousef Atoum $\$$ atoum @yu.edu.jo 9 Counseling and Educational Psychology Dept. Yarmouk University, Shafiq Irshidat st. Irbid, Jordan.

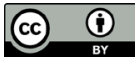

(C) 2019 The Author(s). Published by Enviro Research Publishers.

This is an 2 Open Access article licensed under a Creative Commons license: Attribution 4.0 International (CC-BY).

Doi: http://dx.doi.org/10.12944/CRJSSH.2.2.05 
that allow an individual to explain failure when success in the future is uncertain (Wusik, 2013) or any act that allows a person to attribute failure on a mission to external factors and its success in internal factors (Kazemi, Nekmanish and Kosrafi, 2015).

Nordbooten (2011) defined self-handicapping as any action or choice that would enhance the chance of failure to protect oneself, while Palmer (2013) defined it as creating individuals barriers to their success as an excuse for their failure. Kazemi, Nekmanish and Kosrafi (2015) defined it as any act that allows a person to attribute failure on a mission to external factors and its success in internal factors. Decker and Mitchell (2016) pointed out that self-handicapping is a predetermined strategy with tow pretentious variables using excuses for potential failure as a disease or behavior as creating an obstacle to reduce the effort for a particular task.

Examples of self-handicapping behaviors are carried out by students in various situations before or during or after assignments and exams such as lack of time, claiming difficulty of the task, more or less sleep, requesting delay of the exam and claim of being sick (Decker \& Mitchel, 2015; Javanmard, Hoshmadja \& Ahmadzede, 2012; Kazemi, Nikmanesh \& Khosravi, 2015; Wusik, 2013).

Self-handicapping has two important tribal functions that occur before performing the task, where the individual places a ready excuse and blames the obstacles to the expected failure when threatened. If the situation is good, individuals can say that they overcame the handicap in his ability. The second functions help to deal with the expected weak performance (Litvinova, Balarabe \& Mohammed, 2015).

A basic principle of self- handicapping is the principle of discounting and increasing. The principle of deduction refers to the fact that when the individual handicap himself in a particular task and provides an excuse for failure, it reduces the failure rates because of its efficiency and gives it an excuse (Litvinova, Balarabe \& Mohammed, 2015). The principle of increase indicates that if success occurs despite the presence of obstacles, it indicates the efficiency of the individual, and the increase is because the good performance occurred despite the existence of obstacles that leads to the promotion of self- esteem has (Wusik, 2013).

The types of self-handicapping are classified into two categories: behavioral self-handicapping that refers to actual behavior, and self-reflexive handicapping that refers to non-verbal behavioral traits (Tadik, et al., 2017). Behavioral handicapping is more damaging because it gives less chances of success but at the same time is more persuasive than pretense (Sahrance, 2011). Examples of self-behavioral handicapping are drug abuse, stress reduction and over- stress (Schwinger, et al., 2014). The self- reflexive handicapping reflects general anxiety, stress and moods from exams or health problems (Tadik, et al., 2017; Sahrance, 2011).

Rhodewalt and Tragakis (2011) pointed out that one of the reasons for resorting to self-handicapping is the desire to protect one self and the public reputation and the belief of individuals that their ability is relatively consistent with the lack of self-confidence, which leads to self-handicapping. Cherry (2017) pointed out that the individual resort to handicapping himself because there is strong need to blame the failure on external causes in order to protect self-esteem. Blad (2017) believes that the reason for the individual's self-handicapping is fear of failure and pointed out that low self-efficacy is one of the reasons why an individual engages in self-handicapping behaviors.

The concept of self-efficacy refers to the individual's feelings about himself and his abilities, whether an individual will achieve specific goals or abandon them and seek justifications (Atoum and Al-shoboul, 2018). According to Bandura (1994), the individual's attitudes, abilities and self-discipline plays a major role in how one perceives an individual's performance of a task and how he responds to and acts on other tasks. Bandura defined self-efficacy as the individual's beliefs about their ability to accomplish specific levels of performance tasks in their lives. Qatami (2004) defined it as the self- expectations of the individual about his ability to perform the behavior that achieves the desired results in a particular situation and how to perform the tasks carried out and predict the extent of effort and perseverance required in the achieving that task. 
In addition, Animasaun and Abegunrin (2017) refer to self-efficacy as the students' confidence in their ability to carry out such academic tasks as preparing for exams and writing term papers.

Self-efficacy is determined through four interactive core processes including cognitive, motivational, emotional processes and selection processes (Yadak, 2017). Self-efficacy affects behaviors through the choice of the position, which has the ability to control its problems and requirements, and effort exerted by the individual to solve a particular problem and the perseverance of striving to overcome difficult situations (Atoum and Al-Momani, 2018; Radwan, 1997).

Individuals with low self-efficacy are expected to show higher levels of self-handicapping since lowskilled individuals have doubts about their abilities and difficulty in achieving their goals, abandon them, and don't make enough effort to achieve them. This leads to the use of self-handicapping to justify their failure and attribute it to the obstacle that has been used.

Few studies addressed the relationship between self-efficacy and self-handicapping. However, more studies addressed the relationship between self-handicapping and other variables such as achievement (Schwinger, Wirthwein, Lemmer \& Steinmayr, 2014), perfectionism (Hutuleac, 2014), anxiety and social support (Kalyon, Dadandi \& Yazici, 2016), personality traits (Prpa, 2017), cheating (Barzegar \& khezri, 2012).

Javanmard and Hoshmandja and Ahmadzade (2012) showed a negative relationship between self-handicapping and academic achievement, and showed that self-handicapping and self-efficacy are important indicators of academic achievement. Kazem, Javady and Masoud (2013) showed that self-efficacy is linked to a negative correlation with academic self-handicapping and females have better academic self- efficacy than males, and males suffer more academic self-handicapping than females.

Nosenko and Arshava also Nosenko (2016) showed that emotional interaction is one of the main personal predictors of self-handicapping. Also, Firoozi, Zadebagheri, Kazemi and Karami
(2016) showed that there was a positive relationship between anxiety testing, negative coping, and self-handicapping. Individuals suffering from anxiety and negative evaluation suffer from a decrease in self-efficacy, who are more likely to use self-handicapping.

\section{The Problem of the Study and its Questions}

The behaviors of university students indicate that some of them tend to blame their failure on external factors with every bad test result. They show many excuses and obstacles to justify their failure. Repeating those behaviors may be a problem because they may have negative effects on students and their perception of their competence, self-esteem and their sense of negative beliefs towards their real potential to achieve their success in the future. The researchers believe that one of the reasons behind these behaviors refers to self-handicapping where the students' sense of inability and lack of self-efficacy relate to students' increased self-handicapping. Therefore, this study aimed to identify the level of self-handicapping in the light of some variables and the relationship with self-efficacy among Yarmouk University student. The study tried to answer the following question.

1. What is the level of self-handicapping among Yarmouk University students?

2. Are there statistically significance $(a=0.05)$ differences in the level of self-handicapping among Yarmouk University students due to gender, specialization and achievement levels?

3. Is there a statistically significant correlation between self-handicapping and self-efficacy?

\section{The Significant of Studying}

The significant of the current study is evident through the lack of local studies dealing with self-handicapping and lack of studies that correlate self-handicapping to self-efficacy. In practice, these results can contribute to increasing the awareness of university professors, officials and specialists in terms of understanding the nature of the relationship between the two variables and to guide and educate students in the methods that help them to get rid of the behaviors associated with self-handicapping. This study could be the starting point for other 
studies using different population and variables in the Arab region in particular.

\section{Study Terms and Definitions \\ Self-Handicapping}

is an option that prevents individuals from taking personal responsibility for the consequences of their behavior through obstacles so that failure can be blamed on external causes (Cherry, 2017). Operationally, self-handicapping was measured through scores obtained in the self-handicapping scale used in this study.

\section{Self-Efficacy}

Is the belief of individuals about their ability to achieve specific levels of performance tasks in their lives (Bandura, 1994). Operationally, self-efficacy was measured through scores obtained in the self-efficacy scale used in this study.

\section{Method}

The descriptive approach was used to reveal the relationship between self-handicapping and self-efficacy among Yarmouk University students in the light of some variables in order to suit the nature of this study and its objectives.

\section{Population and Sample}

The study population consisted of (25000) undergraduate students at Yurmouk UniversityJordan enrolled in the second semester of the academic year (2017-2018). The sample consisted of (818) male and female students, representing about (3\%) of the study population. After excluding (25) questionnaires, the number of valid questionnaires has reached (793) as shown in Table (1).

Table1: Distribution of the sample of the study according to gender and specialization variables

\begin{tabular}{|c|c|c|c|}
\hline Variable & Level/ Category & Number & Percentage $\%$ \\
\hline & Male & 286 & 36.1 \\
\hline \multirow[t]{3}{*}{ Gender } & Female & 507 & 63.9 \\
\hline & Total & 793 & 100.0 \\
\hline & Scientific & 347 & 43.8 \\
\hline \multirow[t]{2}{*}{ Specialization } & Humanitarian & 446 & 56.2 \\
\hline & Total & 793 & 100.0 \\
\hline
\end{tabular}

\section{Study Tools}

To achieve the objectives of the study two tools were used

\section{First}

\section{Self-Handicapping Scale}

After reviewing related scales in Arabic and English, the Rhodewalt Scale (Rhodewalt \& Tragakis, 2011) of self-handicapping was used. This measure consisted of (25) items with a 5-point likert type responses ranging from strongly agree to strongly disagree $(5,4,3,2,1)$. The original researcher obtained good validity and reliability indicators of scale.

\section{Validity}

The scale was presented in its preliminary form after prober translation procedures to (9) university professors specializing in psychological and educational sciences to rate the scale items. Based on the agreement of ( $80 \%)$ or more of the judges, the wording of some items were modified and (7) items were deleted. Also, in order to test for construct validity, the remaining items (18 items) were given to a sample of (46) students from outside the sample of the study. Pearson correlation coefficients were calculated between item scores and scores of the self-handicapping scale. Correlation ranged from ( $0.20-0.47$ ) which were considered good enough to insure validity of the scale.

\section{Reliability}

The stability reliability procedures was used by retesting the validity sample after two weeks. Correlation between the two sets of the data was 
(0.78). Also, consistency reliability on the validity data revealed a Cronbach Alpha of (0.65). These are considered good indicators of reliability.

\section{Second}

The Self-Efficacy Scale

After prober review of previous scales, the scale of Mohsen (2006), which consists of (70) items, was chosen. The eight dimensions were: emotional (11 items), social(11 items), behavioral (8 items), self-confidence (10 items), confidence of others (6 items), insistence the perseverance (7 items), academic knowledge (8 items) and moral ( 9 items). The original researcher obtained good validity and reliability indicators of scale.

\section{Validity}

The scale was presented in its preliminary form to (9) university professors specializing in psychological and educational sciences to rate the scale items. Based on the agreement of $(80 \%)$ or more of the judges, (17) items were deleted and some language changes were made. The scale was applied to a sample of (46) students from outside the sample. Pearson correlation coefficients between items scores (53 items) and both total self-efficacy scores and dimensions scores. Correlations ranged from (.20) to (.66) which are considered good indicators of construct validity.

\section{Reliability}

The stability reliability procedures was used by retesting the validity sample after two weeks. Correlation between the two sets of the data was (0.79) and for the dimensions (0.70-0.84). Also, consistency reliability on the validity data revealed a Cronbach Alpha of $(0.85)$ for the whole scale and (0.61-0.74) for the dimensions. These were considered good indicators of reliability.

\section{Study Variables}

The Study Included the Following Variables The Demographic Variables

- $\quad$ Gender: (Male, Female).

- $\quad$ Specialization: (Art, sciences).

- $\quad$ Achievement: (High: GPA 70\% and above, Low: GPA below 70\%).

\section{The Main Variables}

- $\quad$ Self-efficacy and its dimensions.

- Self-handicapping.

\section{Study Procedures}

- $\quad$ Preparing the tools of the study in its final form after validity and reliability procedures.

- Determining the total number of the study population and choosing the sample procedures.

- $\quad$ Obtaining a letter of approval from Yarmouk University ethical committee.

- Coordination with the office of registration and the faculties of the university to agree on the dates of data collection.

- $\quad$ Students were informed with objectives of the study and informed that data will be used confidentially for scientific purpose only.

- The researchers answered questions by the students.

- $\quad$ Researchers collected the data and prober data analysis was performed.

\section{Results}

To answer the first question, "What is the level of selfhandicapping among Yarmouk University students?, means and standard deviations of scores on the self-handicapping scale were shown in table (2).

Table 2 : Means and standard deviations of self-handicapping scores

\begin{tabular}{|c|c|c|}
\hline Means & S. D. & Items \\
\hline$\overline{4.38}$ & 0.87 & It would be better if I worked harder. \\
\hline 4.12 & 0.93 & My performance is better when I control my feelings. \\
\hline 4.01 & 1.04 & You may someday get everything. \\
\hline 3.98 & 1.00 & I try to do my best regardless of the result. \\
\hline 3.93 & 1.08 & When I try to read my mind it is easily distracted by the inconvenience. \\
\hline 3.82 & 1.02 & $\begin{array}{l}\text { When my performance is bad in something, I am happy to remember that my } \\
\text { performance is good in other things. }\end{array}$ \\
\hline 3.78 & 1.18 & More than eating and drinking multiple times. \\
\hline
\end{tabular}




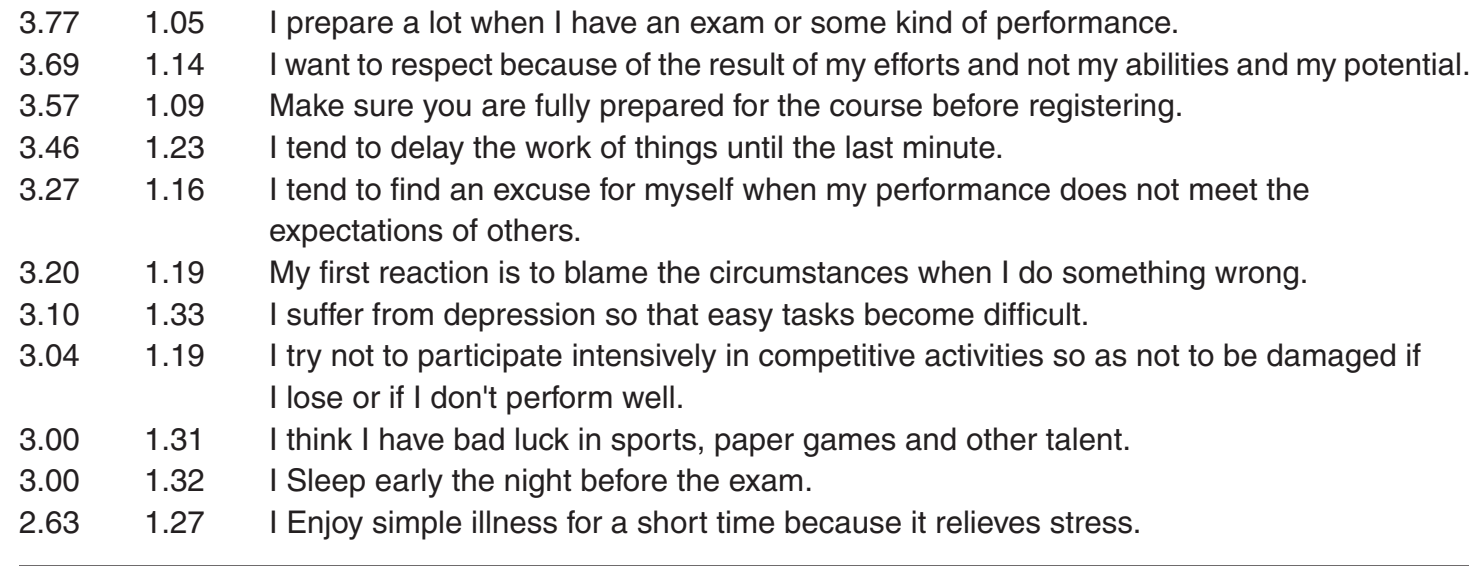

\subsection{4 $0.43 \quad$ Handicapping of the self as a whole}

Table (2) shows that the general level of self-handicapping among Yarmouk University students is around average with a mean of (3.54: $70.8 \%)$ ). Items means ranged from high (4.38: $87.6 \%)$ to low (2.63: $52.6 \%)$.

To answer the second question:" Are there statistically significant differences in the selfhandicapping scores due to gender, specialization and achievement?", means and standard deviations of self-handicapping based on gender, specialization and achievement are shown in table (3).

Table (3) showed that there are apparent differences between the means of self-handicapping according to the variables gender, specialization and cumulative average. To determine the statistical significance of these differences, a 3-way Anova was conducted as shown in table (4).

Table 3: Means and standard deviations of self-handicapping based on gender, specialization and achievement (GPA)

\begin{tabular}{|c|c|c|c|c|c|c|c|}
\hline \multirow{3}{*}{ Gender } & \multirow{3}{*}{ Specialization } & \multicolumn{6}{|c|}{ GPA } \\
\hline & & \multicolumn{2}{|c|}{ Total } & \multicolumn{2}{|c|}{ High } & \multicolumn{2}{|c|}{ Low } \\
\hline & & S.D. & Means & S.D. & means & S.D. & Means \\
\hline \multirow[t]{3}{*}{ Male } & Scientific & 0.52 & 3.49 & 0.51 & 3.52 & 0.53 & 3.40 \\
\hline & Humanitarian & 0.45 & 3.53 & 0.46 & 3.54 & 0.41 & 3.52 \\
\hline & Total & 0.49 & 3.51 & 0.49 & 3.53 & 0.49 & 3.45 \\
\hline \multirow[t]{3}{*}{ Female } & scientific & 0.38 & 3.57 & 0.39 & 3.56 & 0.31 & 3.59 \\
\hline & Humanitarian & 0.40 & 3.56 & 0.39 & 3.56 & 0.43 & 3.53 \\
\hline & Total & 0.39 & 3.56 & 0.39 & 3.56 & 0.37 & 3.56 \\
\hline \multirow[t]{3}{*}{ Total } & scientific & 0.45 & 3.53 & 0.44 & 3.55 & 0.48 & 3.47 \\
\hline & Humanitarian & 0.41 & 3.55 & 0.41 & 3.55 & 0.42 & 3.53 \\
\hline & Total & 0.43 & 3.54 & 0.42 & 3.55 & 0.45 & 3.49 \\
\hline
\end{tabular}

Table (4) showed that there are no statistically significant deference's at the level of statistical significance $(a=0.05)$ on self-handicapping scores due to the variables (gender, specialization, and achievement) or the interaction between the independent variables. 
To answer the third question: " is there a statistically significant correlations between self-handicapping and self-efficacy", Pearson correlation coefficients were calculated among the sample of the study between self-handicapping and self-efficacy and its dimension as shown in table(5).
Table (5) showed that there were statistically significant negative correlations between self-esteem and its dimensions (except behavioral self-efficacy) with self-handicapping ranging from $(-.274)$ to $(-.082)$.

Table 4: Analysis of 3-way a nova on self-handicapping scores based on gender, specialization and cumulative average

\begin{tabular}{llllll}
\hline Variable & $\begin{array}{l}\text { Total } \\
\text { squares }\end{array}$ & $\begin{array}{l}\text { Degree of } \\
\text { freedom }\end{array}$ & $\begin{array}{l}\text { Average } \\
\text { squares }\end{array}$ & $\begin{array}{l}\text { Value } \\
\mathbf{p}\end{array}$ & $\begin{array}{l}\text { Statistical } \\
\text { significance }\end{array}$ \\
\hline Gender & 0.37 & 1 & 0.37 & 2.021 & 0.156 \\
Specialization & 0.029 & 1 & 0.029 & 0.161 & 0.689 \\
Cumulative average & 0.102 & 1 & 0.102 & 0.558 & 0.455 \\
Gender x specialization & 0.237 & 1 & 0.237 & 1.296 & 0.255 \\
Gender x cumulative age & 0.089 & 1 & 0.089 & 0.485 & 0.486 \\
Specialization x cumulative average & 0.018 & 1 & 0.018 & 0.099 & 0.753 \\
Gender x specialization x cumulative & 0.144 & 1 & 0.144 & 0.787 & 0.375 \\
The error & 143.69 & 785 & 0.183 & & \\
\hline Total & & & & & \\
\hline
\end{tabular}

Table 5: Pearson correlation coefficients among the sample of the study sample (Yarmouk University students) on the scale of self-handicapping as a whole and the measure of self-efficacy and its dimensions

\begin{tabular}{lll}
\hline Dimensions the self-efficacy scale & \multicolumn{2}{l}{$\mathbf{R}$} \\
\hline Emotional & Coefficient of correlation & $-.274^{\star *}$ \\
Social development & Statistical significance & 0.000 \\
& Coefficient of correlation & $-.186^{\star *}$ \\
Behavior & Statistical significance & 0.000 \\
& Coefficient of correlation & -0.051 \\
Self-confidence & Statistical significance & 0.149 \\
& Coefficient of correlation & $-.230^{\star *}$ \\
Trust of others & Statistical significance & 0.000 \\
& Coefficient of correlation & $-.135^{\star *}$ \\
Persistence and perseverance & Statistical significance & 0.000 \\
& Coefficient of correlation & $-.273^{\star *}$ \\
Cognitive academy & Statistical significance & 0.000 \\
& Coefficient of correlation & $-.082^{*}$ \\
The moral & Statistical significance & 0.022 \\
& Coefficient of correlation & $-.135^{\star *}$ \\
Self-efficacy as a whole & Statistical significance & 0.000 \\
& Coefficient of correlation & $-.236^{\star *}$ \\
& Statistical significance & 0.000 \\
\hline
\end{tabular}




\section{Discussion}

The results of the study showed that there was an average level of self-handicapping among Yarmouk University students, this can be explained by the fact that students may sometimes learn that threatening situations may affect their self-esteem as a result of fear of failure which could reflect on their abilities to perform specific tasks (Schwinger, et al., 2014). The average level of self-handicapping may also be due to students' desire to protect themselves and their public reputation in front of others(Sarwat \& Frasat, 2014; Firoozi, et al., 2016), or may be due to reasons that may be attributed to the university`s teaching strategies, curriculum and learning method which may be inappropriate for university students (Ganim, 2017).

Many other factors may explain the average level of self-handicapping such as lack of confidence, feelings of inferiority, desire to obtain high grades and lack of social-academic support (Kalyon, Dadandi \& Yazici, 2016 : Ganim, 2017).

Results also indicated that there are no statistically significant differences among self-handicapping levels due to gender, specialization and achievement. These findings may explain that the trait of self-handicapping is not related to such factors and other factors may play a role in explaining the variation in self-handicapping such as emotional, social and cognitive factors (Blad, 2017; Rhodewalt \& Tragakis, 2001). Gender differences in previous studies vary in terms of finding differences or lack of differences (Hutuleac, 2014; Kalyon, Dadandi \& Yazici, 2016; Prpa, 2017 ; Barzegar \& Khezri, 2012; Kazem, Javady \& Masoud, 2013; Sarwaat \& Frasat, 2014; Schwinger, et al., 2014). The gender effect of self-handicapping needs further investigations across culture to determine social and cultural factors mediating these gender differences.

The results of this study also showed that there were statistically significant negative correlations between self-esteem and its dimensions (except behavioral self-efficacy) with self-handicapping. This can be explained by the fact that one of the reasons people tend to resort to self-handicapping behaviors is the low self-efficacy, which leads students to mistrust their abilities and competence and to avoid the tasks trusted to them (Bandura, 1994), which threatens their reputations and impede there self-handicapping in order to protect themselves, divert attention from their competence and protect themselves from failure.

The negative correlations between the scores of self-handicapping and self-efficacy can also be explained by the fact that students may have some sense of inferiority ( Rhodewalt \& Tragakis, 2011), negative feelings and misunderstanding for themselves (Yadak, 2017), who may feel anxious, tense and desperate when faced with difficult task (Kalyon, Dadandi \& Yazici, 2016). The negative correlations can also be explained by the persistence and perseverance of the individuals in the study sample who may have a lack of motivational processes that regulate their motivation. Bandura (1994) points out that motivational processes in self-efficacy determine the motivation, the goal, the amount of effort and consistency to face failure and reach success.

The negative correlations between self-handicapping and self-efficacy are consistent with many previous studies (Kazem, Javady \& Masoud, 2013; Firoozi, Zadebagheri, Kazemi et al., 2017).

\section{In the light of the findings of the study, the researchers recommend}

- To raise awareness among educators about the danger of using self-handicapping and its role in reducing the chances of success of the student.

- Reducing students fear of failure by verbal persuasion and social support and directing them to realistic goals because the reasons that lead students to resort to self-handicapping are fear of failure, lack of verbal persuasion and social support.

- Conduct further studies to test the effect of personality traits, social, cognitive and emotional factors on self-handicapping. 


\section{Funding}

The author(s) received no financial support for the research, authorship, and/or publication of this article.

\section{Conflict of Interest}

The authors do not have any conflict of interest.

\section{References}

1. Adnan Yousef Atoum, Abdolatif Al-Momani. Perceived Self-Efficacy and Academic Achievement among Jordanian Students. Trends Tech Sci Res. 2018; 3(1): 555602.

2. Al-Momani \& Atoum (2016). Cultural Intelligence among Jordanian University Students. International Journal of Education and Training (InjET), 2(1): 1- 9.

3. Animasaun, I.L. and Abegunrin, O.A. (2017) 'Gender difference, self-efficacy, active learning strategies and academic achievement of undergraduate students in the Department of Mathematical Sciences, Federal University of Technology, Akure, Nigeria'. Int. J. Teaching and Case Studies, 8(4), 255-280.

4. Atoum, A. \& Al-Shoboul, R. (2018). Emotional support and its relationship to Emotional intelligence. Advances in Social Sciences Research Journal, 5(1), 7-16, Dol:10.14738/ assrj.51.4095.

5. Bandura, A. (1994). Self-Efficacy. Encyclopedia of human behavior, 4, 71-81.

6. Barzegar K. and Khezri H. (2012). Predicting academic cheating among the fifth grade students: The role of self-efficacy and academic self-handicapping. J. Life Sci. Biomed. 2(1), 1-6.

7. Blad, E. (2017). The Unexpected reason some students procrastinate. Retrieved on 5-12-2017 from http:॥ www. Forbes. com.

8. Cherry, K. (2017). Self-Efficacy: Why believing in yourself matters. Retrieved on 11-12-2017 from http:॥ www. Verywell.Com.

9. Decker, F. \& Mitchell, J. (2016). Why self-handicapping leadership is a hurtful strategy. Retrieved on 9-12-2017 from https:॥ Manga.magazine.Com.

10. Decker, P. \& Mitchell, J. (2015) .Introduction to self-handicapping leadership: The nine behaviors holding back employees, Managers, And companies, and how to overcome them. Retrieved on 11-10- 2017 from Https:// www.
Informit.com.

11. Firoozi, M., Zadebagheri, G, Kazemi, A. \& Karami, M. (2016). An investigation on the relationship between perfectionism beliefs, self-effcacy, and test anxiety with selfhandicapping behaviors. International Journal of Behavioral sciences, 10 (3) '94- 98.

12. Ganim, S. (2017). Academic self-handicapping and its relation to deep thinking. Master Thesis, Yarmouk University, Jordan.

13. Hutuleac, A. (2014). Perfectionism and selfhandicapping in a dult education. Procedia social and behavioral sciences, 142, 434-438.

14. Javanmard, A., Hoshmandja, M. \&Ahmadzade, L. (2012) .Investigating the relationship between self-efficacy, cognitive and mate cognitive strategies, and academic self-handicapping with academic a achievement in male high school students in the tribes of fares province. Journal of life science and biomedicine, 3(1), 27-34.

15. Kalyon, A., Dadandi, I. \& Yazici, H. (2016) . The Relationships between self-handicapping tendency and narcissistic personality traits, anxiety sensitivity, social support, academic achievement. Busunen Adam the journal of psychiatry and neurological sciences, 29, 237-246.

16. Kazem, Z. Javady, Y. \& Masoud, G. (2013). Academic self-efficacy, and self-handicapping in high school students. Development Psychology Journal of Iranian Psychologists ' 9 (34) ' 203-212.

17. Kazemi, Y., Nekmanesh, Z. \& Khosravi, M. (2015). Role of self-handicapping on prediction of the quality of life in primary students. Clinical psychology, 3(1), 16-68.

18. Litvinova, A., Balarabe, M. \& Mohammed, A. (2015) . Influence of personality traits and age on academic self- handicapping among under graduate students of ahmadu bello university, Zaria, Nigeria. Psychology,(6) ' 1995-2003 .

19. Mohsen, A. (2006). Self-efficacy as related 
personality traits. Master Thesis, Yarmouk University, Jordan.

20. Nosenko, E.'Arshava, I. \&Nosenko, D. (2016) . Personality predictors of self- handicapping as behavioral manifestation of the individual's self-efficacy defect. International Journal of Personality Psychology' 2 (1) 44-50.

21. Palmer, B. (2013) Self-handicapping-applied social psychology (ASP). Retrieved on the applied social psychology asp, on 28/9/2017 from: http://www.personal.pusu.edu.

22. Prpa, N.(2017). Personality traits and gender effect on athletes and non-athletes self-handicapping strategies over time. Eqol Journal, 9(1), 5-14.

23. Qatami, Y. (2004). Social cognitive theory and its applications. Amman: Dar Elfikr publishing and distribution.

24. Radwan, S.(1997). Self-efficacy expectations of "Theoretical construction and measurement". Sharjah journal of social affairs, 14 (25), 25-51.

25. Rhodewalt, F. \& Tragakis, M. (2011). Selfhandicapping and the social self: The cost and rewards of inter personal self-construction. Inform fourth annual Sydney symposium of social psychology, march 19-22,University of Utah.
26. Sahrance, U. (2011). An investigation of the relationships between self-handicapping and depression, anxiety, and stress. International online journal of educational sciences, 3(2), 526-540.

27. Sarwat, S. \& Frasat, k. (2014) . Gender differences in self-handicapping: the role of self-esteem and fear of negative evaluation. Journal Of Gender \& social issues, 13 (1) 45-56

28. Schwinger, M., Wirthwein, L., Lemmer, G. \& Steinmayr, R. (2014). Academic selfhandicapping and achievement: A metaanalysis. Journal of educational psychology, 106(3), 744-761.

29. Tadik, H., Akca, E., \& Ucak-Azboy, Z. (2017). Perfectionism and self-handicapping behaviors of gifted students. Journal for the education of gifted young scientists, 5(2), 85-93.

30. Wusik, M. (2013). Socially positive behaviors as self- handicapping. Master thesis, The faculty of the Virginia polytechnic institute and state university in partial fulfillment.

31. Yadak, S. (2017). The Impact of the perceived self-efficacy on the academic adjustment among qassim university undergraduates. Open journal of social sciences, 5, 157-174. 